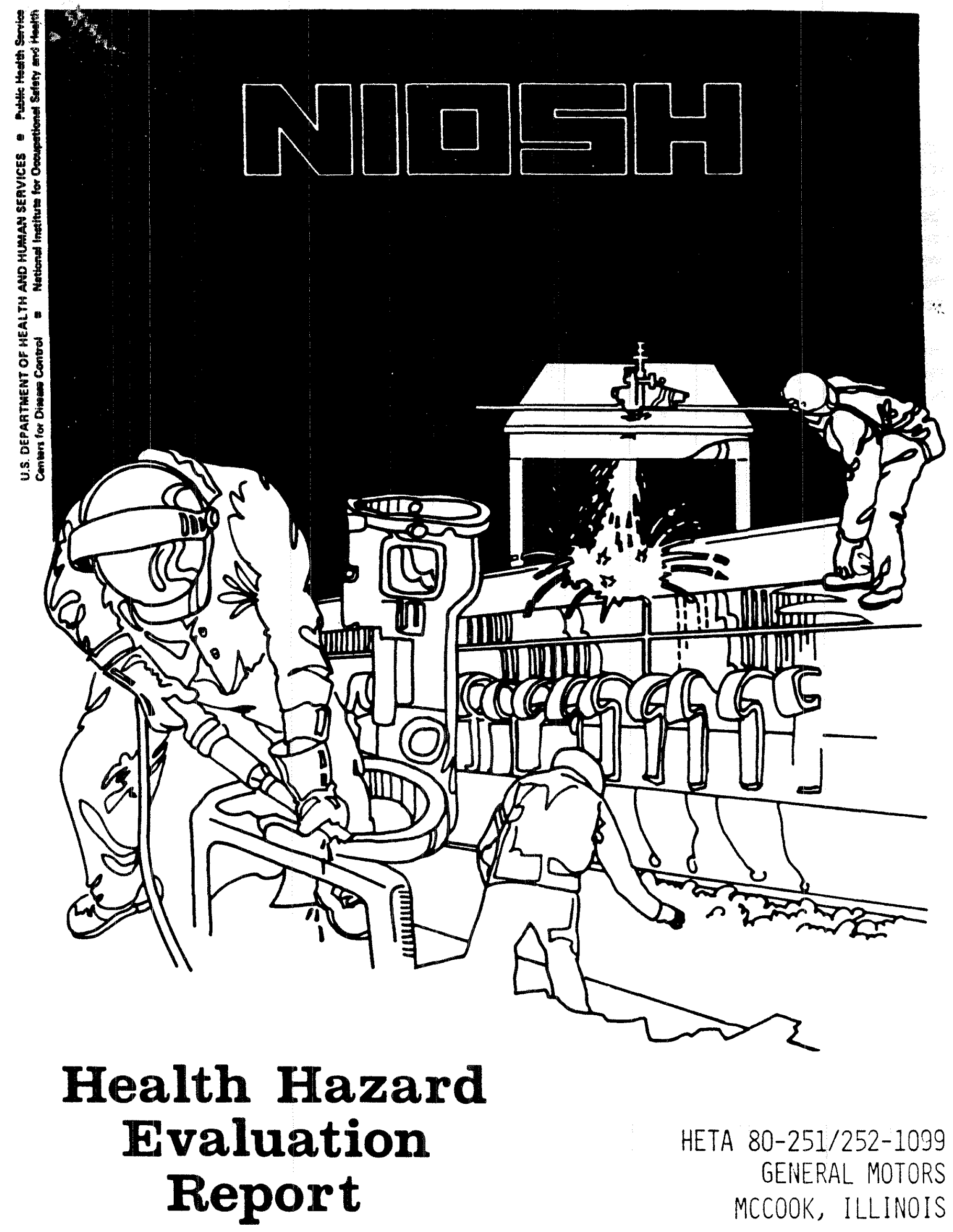


The Hazard Evaluations and Technical Ass istance Branch of NIOSH conducts field investigations of possible health hazards in the workplace. These investigations are conducted under the authority of Section $20(a)(6)$ of the Occupational Safety and Health Act of 1970, 29 U.S.C. 669(a)(6) which authorizes the Secretary of Health and Human Services, following a written request from any employer or authorized representative of employees, to determine whether any substance normally found in the place of employment has potentially toxic effects in such concentrations as used or found.

The Hazard Evaluations and Technical Assistance Branch also provides, upon request, medical, nursing, and industrial nygiene technical and consultative ass istance (TA) to Federal, state, and local agencies; labor; industry and other groups or individuals to control occupational health hazards and to prevent related trauma and disease.

Mention of company names or products does not constitute endorsement by the National Institute for Occupational Safety and Health. 
I. SUMMARY

On September 16, 1980, the National Institute for Occupational Safetv and Health (NIOSH) received a request from the United Auto Workers Lncal 719 for a health hazard evaluation of the General Motors Electro-Motive Division in McCook, Illinois. NIOSH was asked to investigate symptoms of headache, dizziness, nausea and eye irritation in the varnish impregnating area, and reports of sore throats, respiratory irritation and eye irritation in the battery charging area.

NIOSH conducted site visits at the plant on September 29-30 and November 11-14, 1980 to obtained personal and area air samples and to conduct worker interviews.

A combustible gas meter survey determined levels which ranged from $1 \%$ of the lower exposure limit (LEL) at the floor near the varnish impregnating tanks to $38 \%$ of the LEL at the rim of the impregnating tanks while they were being opened. Personal air sampling for a mixture of solvents in the area (n-hutyl acetate, toluene, xylene, ethyl benzene, methyl ethyl ketone and isobutanol) ranged from $1 \%$ to $17 \%$ of the permissible exposure limit (PEL) for mixtures. A case-control analysis of workers in the department indicated that the risk of symptoms of solvent intoxication was significantly increased if work was stationed less than 30 feet from the impregnating tanks. Seven of eight workers stationed less than 30 feet from the impregnating tanks, experienced symptoms compared with on ly three cases out of 13 workers stationed 30 feet or more from the tanks.

Eleven personal air samples for sulfuric acid mist in the battery charaing area ranged from below the 1 imit of detection to $0.027 \mathrm{mg} / \mathrm{M}^{3}$ (PEL $-1 \mathrm{mg} / \mathrm{M}^{3}$ ).

Fourteen personal air samples for arsine in the hattery charging area wero below the limit of detection. Fourteen personal air samples for stibine ranged from N.D. to $0.0011 \mathrm{ppm}$ (PEL - $0.1 \mathrm{ppm}$ ). Four personal samples for inorganic arsenic ranged from 0.069 to $0.211 \mathrm{ug} \mathrm{M}^{3}$ ( $\mathrm{PEL}-2.0 \mathrm{ug} / \mathrm{M}^{3}$ ). Medical questionnaire results indicated that workers stationed within 100 feet of the battery charging area had significant increases in the reporting of sore throat, eye pain, and respiratory complaints (cough, phleam, or shortness of breath). Persons with chronic mucous membrane or respiratory irritation with onset after the installation of the battery charging area were compared to those without such history. Proximity to the battery charaing area was a significant risk factor with one person with symptoms reported amono the 12 persons working more than 50 feet from the battery charging station and thirteen persons with symptoms among the 16 workers stationed closer than 50 feet $(p<.001)$.

Based on these results, NIOSH determined that the risk of symptoms of solvent

intoxication was significantly increased for workers within 30 feet of the varnish impreanating tanks. These symptoms may he caused by the short-term, high levels (up to $38 \%$ of the $L E L)$ of solvent vapors which are released when the impregnating tanks are opened. Cases of chronic mucous membrane irritation or respiratory irritation were significantly associated with proximity to the hattery charging station. Low levels of sulfuric acid, arsine and stibine retected in the area may be responsible for these symptoms. Recommendations to control these exposures are contained in Section VII of this report.

REYWOROS: SIC 3T43 Varnish impreanatina, hattery charging stations, mixed soTvent exposures, sulfuric acid, arsine, stibine, inorganic arsenic, solvent intoxication, z.... 
Page 2 - Health Hazard Evaluation Report No. B0-251-252

II. INTRODUCTION

On September 16, 1980, the National Institute for Occupational Safety and Health (NIOSH) received a request from the United Auto Workers, Local 719, for a health hazard evaluation of the General Motors Electro-Motive Division in McCook, Illinois. NIOSH was requested to evaluate present working conditions and practices in two areas: the traction motor armature impregnating department, and the battery charging station.

The requestor was concerned about potential exposures to varnish vapors near the impregnating tanks and baking ovens. Employees in this area were reported to have complained of headaches, dizziness, nausea and eye irritation. Employees in the area of the battery charging station had reported symptoms of sore throats, respiratory irritation and eye irritation.

The NIOSH industrial hygienist and medical officer met with representatives of General Motors and the United Auto Workers for the opening and closing conferences, walk-through survey, and discussions of environmental sampling and medical interviews on September 29 and 30 , 1980. Discussions with management concerned process description, engineering controls, composition of the impregnating varnish, health surveillance monitoring, personal protective equipment, work practices, and environmental and medical monitoring for the areas in question. Employee interviews focused on the job description, exposure histories, work practices, maintenance procedures and associated health problems. During this visit, area air sampling was conducted in the varnish impregnating and battery charging departments.

A follow-up survey was conducted on November 11-14, 1980. Personal and area air samples were obtained in the battery charging and varnish impregnating departments. Additional medical interviews were conducted in these departments. Interim Report No. 1, which contained the results of medical interviews and preliminary environmental findings, was issued by NIOSH in December, 1980.

III. BACKGROUND

The Electro-Motive Division of General Motors is engaged in the production of diesel engines and railroad locomotives. The diesel engines on the locomotives generate electricity which is used to power direct current traction motors located between the trucks (wheels) on the underframe of the locomotive. Due to their proximity to the roadbed, the traction motors are coated with varnish to prevent damage by corrosion and accumulation of road grime.

The traction motor armatures are partially assembled in the varnish impregnating area. The armature is wrapped with layers of copper wire and insulation, brushed with shellac, and placed in an electric Binks 
Page 3 - Health Hazard Evaluation Report No. 80-251-252

oven. The armatures are heated at $105^{\circ} \mathrm{C}$ for $21 / 2$ hours and allowed to partially cool. Three armatures are loaded in the impregnating tank, and the cover is sealed. A vacuum is created in the impregnating tank and varnish is let in from the holding tank until it reaches the level of the riser on the armatures. The pressure is increased to $150 \mathrm{psi}$ (pounds per square inch) for half an hour to force the varnish into the armature. The varnish is drained, and the armatures are removed. The pinion end of the armature is dipped in xylene and scrubbed with a brush until clean. The armatures are then placed in rollover ovens to cure the varnish. The rollover ovens consist of banks of infrared lights which heat the armature, while it rotates on a spit, to $180^{\circ} \mathrm{C}$ for 2 $1 / 2$ hours. The day and swing shift each produce 12 armatures per shift. The night shift makes six.

The battery charging station consists of $38,24-\mathrm{Volt}$ chargers and 18 , 36-Volt chargers which are arranged in three rows. Batteries are placed on charge and removed for use as required by the truck operators.

\section{EVALUATION DESIGN AND METHODS}

A. Environmental Sampling

1. Varnish Impregnating Department

During the initial visit air sampling in the varnish impregnating department focused on the organic vapors which were driven off the traction motor armatures as the varnish was cured in the infrared rollover ovens. Area samples were collected on charcoal tubes positioned as close to the process as possible. These charcoal tubes were analyzed qualitatively by gas chromatography-mass spectrometry, and the results were utilized to plan sampling during the follow-up visit. On the return visit, personal and area air samples were obtained throughout the varnish impregnating department for $n$-butyl acetate, ethyl benzene, xylene, toluene, methyl ethyl ketone (MEK) and isobutanol. These samples were collected on charcoal tubes using portable sampling pumps calibrated at $100 \mathrm{cc}$ (cubic centimeters) per minute and analyzed by gas chromatography following NIOSH Method P\&CAM 127, 1 with the exception of isobutanol which was analyzed following NIOSH Method F-64.2. An MSA Model 40 Combustible Gas Indicator was used to survey the area near the impregnating tanks.

2. Battery Charging Area

In the battery charging area, air sampling during the initial visit was limited to area samples taken at 18 " above the batteries. Arsine samples were collected on charcoal tubes utilizing portable pumps with a flow rate of $200 \mathrm{cc} / \mathrm{min}$. Sulfuric acid samples and arsenic samples were collected on 
Page 4 - Health Hazard Evaluation Report No. 80-251-252

mixed cellulose ester membrane filters (0.8 um pore size) with portable pumps at a flow rate of $2 \mathrm{l} / \mathrm{min}$. Additional sampling for arsine and ozone was executed with detector tubes which show a colorimetric change if the gas is present. On the follow-up visit to the battery charging station, personal and area samples were taken for arsine, stibine, inorganic arsenic, and sulfuric acid utilizing the collection method described above.

Area samples were obtained at the battery charging stations, on the wall separating the battery charging area from other work areas and at the surface grinder which is located next to the battery charging area (See Figure 1 ).

Sulfuric acid samples were analyzed by ion chromatography on a Dionex Model 10 ion chromatograph. According to NIOSH Method P\&CAM $268^{3}$ the detection limit was $5 \mathrm{ug} \mathrm{H}_{2} \mathrm{SO}_{4} /$ filter.

Charcoal tube samples were analyzed for arsine and stibine by a hydride generation procedure. The samples were ashed in a mixture of nitric and perchloric acids. Sulfuric acid was used to remove any remaining perchloric or nitric acid, since these interfere with the hydride generation procedure.

The samples were then analyzed for arsenic and antimony by reacting them with sodium borohydride to produce their gaseous hydrides and burning the resulting hydrides in a furnace placed in the light path of an atomic absorption spectorphotometer. The limit of detection for this analysis was $65 \mathrm{ng}$ per sample for arsine and $75 \mathrm{ng}$ per sample for stibine.

Filter samples were analyzed for arsenic using arsine generation technique on an IL353 atomic absorption spectrophotometer. For more information on the technique, refer to the article entitled "An Automated Technique for Sub-microgram Determination of Selenium and Arsenic in Surface Waters by Atomic Absorption Spectroscopy" by Pierce, Lamoneaux, Brown and Fraser in the January/February 1976 volume of "Applied Spectroscopy". The limit of detection is estimated to be $25 \mathrm{ng}$ of arsenic per filter.

\section{B. Evaluation Criteria}

The sources of criteria used to assess workroom concentrations of air contaminants were 1) Recommended Threshold Limit Values (TLV's) and their supporting documentation as set forth by the American Conference of Governmental Industrial Hygienists (ACGIH) 1980; 2) Occupational Safety and Health Administration (OSHA) Standards (29 CFR 1910), July, 1980; and 3) NIOSH Recommendations for Occupational Health Standards. These standards/criteria are summarized in Table I. In instances where these standards/criteria 
Page 5 - Health Hazard Evaluation Report No. 80-251-252

vary, the most recent or most restrictive criterion should be used for comparison to actual measured levels. This practice ensures maximum protection in the workplace.

When two or more hazardous substances are present, their combined effect, rather than that of either individually, should be given primary consideration. The ACGIH4 has proposed the following formula for components in a mixture which have similar toxicological effects:

$$
\frac{C_{1}}{T_{1}}+\frac{C_{2}}{T_{2}}+\frac{C_{3}}{T_{3}}+\cdots \cdot \frac{C_{n}}{C_{T}}
$$

Where $C_{1}$ indicates the observed atmospheric concentration and $T_{1}$, the corresponding threshold limit. If the sum exceeds unity, then the TLV of the mixture should be considered as being exceeded. This formula was used to calculate the TLV of the mixture of organic vapors detected in the varnish impregnating area.

\section{Medical Evaluation}

Workers in three areas of the plant were requested to participate in the medical study: Group I consisted of all machine operators within 100 feet of the battery charging area; Group II consisted of machine operators, working with similar type machines, working more than 200 feet from the battery charging area; and Group III consisted of all workers within 100 feet of the armature varnish dip-tanks. All workers who met the above criteria were asked to participate, with the exception that a stratified random sample of one-third of the workers on the evening and night shift were selected. The study consisted of a medical questionnaire including a symptom survey, past medical history, work history, and a physical examination of skin, head, neck and chest.

V. RESULTS

A. Environmental

1. Varnish Impregnating

On area air samples collected september 29,1980 on charcoal tubes near the rollover ovens, the major compounds identified were $n$-butyl acetate, ethyl benzene, xylene, toluene, and a series of alkanes in the $\mathrm{C}_{9}-\mathrm{C}_{12}$ range, similar to a mineral spirits type bulk. A bulk sample of the varnish, which had been obtained on the initial visit, was put in a sealed vial and heated 1-2 hours at about $180^{\circ} \mathrm{C}$. Major peaks identified in this sample were $n$-butyl acetate, ethyl benzene, xylene, toluene and $\mathrm{C}_{9}-\mathrm{C}_{12}$ alkanes. Minor peaks included isobutanol and methyl ethyl ketone. A solution of the bulk varnish itself was analyzed by gas chromatogram only. The chromatogram 
Page 6 - Health Hazard Evaluation Report No. 80-251-252

obtained from this sample looked identical to that of the charcoal tube samples.

Table II indicates the results of the combustible gas meter survey. Readings taken at the rim of the impregnating tank during opening procedures ranged from $19 \%$ to $38 \%$ of the lower explosive limit (LEL). The National Fire Protection Association (NFA) 5 standard for dip tanks containing flammable or combustible liquids states that any vapor concentration exceeding 25 percent of that required to produce a lower flammable limit mixture is considered dangerous from fire or explosion.

Each impregnating tank has 4 small local ventilation hoods, approximately 6" by 4", which are distributed around the impregnating tank. Their face velocities averaged $1200-1400 \mathrm{fpm}$ (feet per minute), but smoke tube measurements taken at the rim of the impregnating tank, approximately 6" from the hoods, demonstrated that they did not capture the smoke. Detector tube measurements for ozone near the rollover ovens showed no detectable levels.

The results of 48 personal and area air samples obtained November 11 and 12, 1980 are contained in Table III. In general, the concentrations measured were well below the established environmental standards/criteria for the substances measured. Mixture calculations for the personal and area samples collected in the varnish impregnating department ranged from 1 to $5 \%$ of the calculated TLV for the mixture. The highest concentrations were obtained on a 10-minute personal sample worn by the impregnator during opening of the impregnating tank. This sample contained $n$-butyl acetate at $3.8 \mathrm{ppm}$; methyl ethyl ketone at $3.1 \mathrm{ppm}$ and isobutanol at $6.6 \mathrm{ppm}$. The ACGIH formula for TLV's of mixtures determined this mixture to be $17 \%$ of the TLV.

\section{Battery Charging Area}

The results of personal area air samples collected for sulfuric acid are presented in Table IV. Area samples ranged from 0.008 $\mathrm{mg} / \mathrm{M}^{3}$ to $0.040 \mathrm{mg} / \mathrm{M}^{3}$. Personal samples ranged from below the limit of detection up to $0.027 \mathrm{mg} / \mathrm{M}^{3}$ for the large $\mathrm{mill}$ operator at the surface grinder and the tape control G\&R operator. The average concentration for all the sulfuric acid air samples was $0.019 \mathrm{mg} / \mathrm{M}^{3}$; the standard deviation was 0.009 .

Air sampling results for arsine and stibine are contained in Table V. Laboratory analysis of arsine and stibine air samples collected on November 11 and 12, 1980, was delayed until June 15, 1981 , due to equipment malfunction at the NIOSH contract 
laboratory. It is possible that the results underestimate the true concentrations due to degradation of the samples while in storage. Arsine levels ranged from below the limit of detection (65 nanograms Hube) to $0.0041 \mathrm{ppm}$ on an area air sample located at battery station \#41. Arsine was not detected on any personal samples.

On September 29, 1980, detector tube measurements for arsine were taken near the caps of a battery at charging station \#30 which was charging at 40 amps and visibly bubbling fluid through the edge of the cap seal. Arsine levels near the rear caps of the battery were $0.45 \mathrm{ppm}$, arsine levels near the front caps were $0.06 \mathrm{ppm}$. Detector tube measurements at station \#76 showed no colorimetric changes. The OSHA, NIOSH, and ACGIH standards/criteria for arsine are $0.05 \mathrm{ppm}$.

As Table $V$ indicates, stibine levels ranged from below the limit of detection to $0.0023 \mathrm{ppm}$. The highest personal breathing zone exposure was $0.0011 \mathrm{ppm}$ for the radial drill operator.

Table VI shows the results of limited air sampling for arsenic. Airborne levels of arsenic ranged from $0.039 \mathrm{ug} / \mathrm{M}^{3}$ to 0.211 $\mathrm{ug} / \mathrm{m}^{3}$. These levels are well within the most stringent recommended criteria for inorganic arsenic established by NIOSH $\left(2 \mathrm{ug} / \mathrm{M}^{3}\right)$.

B. Medical

A total of 57 workers in the three areas agreed to participate in the medical study. No worker who was requested to participate refused. An exact count of workers who met the selection criteria was difficult since several workers moved in and out of the areas in question during the shift, and seniority or other list of employees in those areas was not readily available. Some selection bias may therefore exist.

1. Battery Charging Area

The purpose of this part of the study was to determine whether workers in the battery charging area were at increased risk of eye, nose, throat and respiratory irritation.

Cross-Sectional Study: Questionnaire results and physical findings were compared between battery charging area workers (Group I) and non-battery charging area workers (Groups II and III). The three groups did not differ significantly in mean age (38.6 for Group I, and 40.9 for Groups II and III, $t=2.01, p<.054$ ) or smoking history, or medication history. The battery charging area had significantly fewer 81 lack and Latino workers however, and their mean 
Page 8 - Health Hazard Evaluation Report No. 80-251-252

length of employment was significantly less 14 years compared with non-battery charging workers 6 years).

As Table VII shows, workers stationed within 100 feet of the battery charging area had significant increases in the reporting of sore throat, eye pain and respiratory complaints (cough, phlegm or shortness of breath). In addition, while not statistically significant, greater prevalences of runny nose, itching skin, nosebleeds, burning skin, painful teeth, conjunctivitis, frequent colds and throat tickling were found in workers in or near the battery charging area, compared with non-battery charging workers. Physical examination showed no significant abnormalities except for recent nosebleeds in two battery charging workers.

These results suggested an increased risk of symptoms of mucous membrane or respiratory irritation in battery charging area workers. To test whether this apparent increase in symptoms among battery charging workers was in fact due to proximity to the battery charging station, and not due to smoking or general smoke or fume irritation, cases of chronic mucous membrane or respiratory irritation (lasting more than two weeks), with onset after the installation of the battery charging area (February, 1980), and not associated with upper respiratory infection, were compared with those without such history. One person reported these symptoms among the 12 persons working more than 50 feet from the battery charging station while there were thirteen reporting symptoms among the 16 workers stationed closer than 50 feet $(p<.001)$.

2. Varnish Impregnating Department

The purpose of this phase of the study was to determine if workers in the varnish impregnating department had an increased prevalence of symptoms of solvent exposure. Also, part of the request was a question whether workers in this area were at increased risk of cancer.

Cross-Sectional Study: Among the 30 varnish impregnating department workers, four (13\%) complained of episodic dizziness at work, ei ght (27\%) complained of nausea while at work, and four (13\%) reported episodes of feeling intoxicated while at work (unrelated to alcohol or other drug use). When analyzed by job category, machine operators had the highest prevalence of these symptoms (Table VIII).

Case-Control Study: To determine whether the reported cases of workers with symptoms of solvent intoxication were in fact due to work as machine operators, or some other factor, a case-control analysis was performed. Cases were defined as a worker in the 
Page 9 - Health Hazard Evaluation Report No. 80-251-252

varnish impregnating department who reported symptoms of numbness, dizziness, nausea or feelings of intoxication while at work or within several hours after work, unrelated to alcohol or other drug use. Cases of possible solvent intoxication were not different from non-cases (among the varnish impregnating dept. workers) in mean age, race, shift worked, or smoking history.

Machine operators had a significantly increased risk of solvent intoxication symptoms compared to armature winders $(6 / 6$ vs $2 / 15 p<$ .005 ). Other workers (including impregnators, wedgers, coi 1 operators and stakers) also had increased frequency of solvent intoxication symptoms compared to armature winders $(6 / 8$ vs $2 / 15, p=$ .006 - see Table VIII). Upon further analysis, however, this may have been due to the fact that most workers except for armature winders were stationed within 30 feet of the impregnating tanks, the point source of most solvent vapors in the department. In all workers, risk of symptoms of solvent intoxication was significantly increased if the worker was stationed less than 30 feet from the impregnating tanks $(7 / 8$ of those less than 30 feet from the impregnating tanks complained of symptoms vs only $3 / 13$ of those further away, $p=.00671$.

VI. DISCUSSION AND CONCLUSIONS

A. Varnish Impregnating Area

The medical study indicates that workers within 30 feet of the varnish impregnating tanks had a significantly increased risk of solvent intoxication symptoms. Air sampling with a direct reading combustible gas meter determined that airborne levels of organic vapors at the rim of the impregnating tank could rise to as high as $38 \%$ of the lower explosive limit. The operators at the impregnating tanks reported that the levels of vapors appear to vary depending on the temperature of the armature when it is placed in the impregnating tank. If the armature is hot, higher levels of vapors may be generated.

Personal and area air samples obtained in the varnish impregnating area were below established standards/criteria for the individual solvents, and in combination as a mixture. A 10-minute personal air sample obtained from an impregnator while he was removing the armature from the impregnating tank indicated solvent concentrations which were $17 \%$ of the TLV for the mixture of solvents - a level which was 3 to 17 times higher than any of the long-term personal samples for solvent mixtures.

After the impregnator opens the lid to the tank, he usually leaves the area until the tank ceases to off-gas. Other workers in the area are not forewarned of the opening of an impregnating tank and, therefore, may be exposed to a short duration, high intensity, 
Page 10 - Health Hazard Evaluation Report No. 80-251-252

exposure to solvent vapors while they continue at their tasks. The NIOSH investigators experienced severe eye irritation and noted strong solvent odors while conducting the combustible gas meter survey during the opening of impregnating tanks. Ventilation at the impregnating tanks was insufficient to control vapors when the lid is raised.

The rollover ovens which are used to cure the varnish were also observed to be emitting solvent vapors during the curing process. Ventilation at the rollover ovens is nonexistent.

In conclusion, the varnish impregnating tanks are point-source emitters of solvent vapors which have health effects consistent with the symptoms reported by the workers in the immediate vicinity. The organic vapor levels detected during opening of the lids of the varnish impregnating tanks represent a potential fire and explosive hazard. The association of symptoms of solvent intoxication with proximity to the impregnating tanks suggest that the short-term high level exposures to solvent vapors may be responsible for the reported symptoms. The assessment of the long term risk of cancer in this group of workers would require numbers of workers greater than those present to detect all but the most severe effects, and would request necessary records of deaths, employment histories, and history of exposures which were not readily available assessment of long term risk, thus, was beyond the scope of this investigation.

\section{B. Battery Charging Area}

The results of the medical study conducted in the battery charging area indicated that workers stationed within 50 feet of the battery charging area had significant increases in the reporting of chance sore throat, eye pain and respiratory complaints. These symptoms are consistent with the effects of exposure to sulfuric acid mist. Employees in this area reported that their symptoms were more severe on humid days when there was a lack of general ventilation. Chronic mucuous membrane or respiratory irritation lasting more than two weeks with the onset after the installation of the battery charging area was significantly higher for workers stationed within 50 feet of the battery charging station when compared to those more than 50 feet from the battery charging station.

Environmental measurements in the battery charging area detected the presence of sulfuric acid, arsine, stibine and inorganic arsenic. On the days of sampling, the sulfuric acid airborne levels range from below the limit of detection to $0.04 \mathrm{mg} / \mathrm{m}^{3}$. The levels of sulfuric acid would be expected to change with number of batteries on charge, charge demand, condition of the batteries, (i.e., cracked, or uncapped), and quality of general ventilation. For example, at 9:10 A.M. on November 13, 1980, one of the days of sampling, only 17 of 38 of the 24 volt charging stations were 
Page 11 - Health Hazard Evaluation Report No. 80-251-252

actively charaing; on 1 y 8 of 1836 volt charging stations were in operation.

Workers in the area reported that they experienced stronger symptoms in the early morning hours (about 7-9 A.M.) which coincides with the period of greatest activity in the battery charging area as fork lift trucks beginning the day shift come in at this time to exchange batteries. Movement of damaged batteries, placing depleted batteries on charge, and loose or improper fitting caps on batteries which have just been placed on charge may lead to higher concentrations of sulfuric acid levels in early morning hours.

Summarizing the results, the medical study demonstrated increases in reported of sore throat, eye pain and respiratory complaints within 50 feet of the battery charging area. These symptoms were not reported to have occurred prior to the installation of the battery charging station, and have reportedly decreased since installation of improved general ventilation in the area. Personal air samples indicated the presence of sulfuric acid in the battery charging area at a mean concentration of $0.016 \mathrm{mg} / \mathrm{M}^{3}$. Although the airborne levels on the days of sampling are below established criteria standards for sulfuric acid, the symptoms reported are consistent with those induced by sulfuric acid. Heightened sensitivity to sulfuric acid or increased levels at other times due to lack of ventilation, or condition of batteries may be responsible for the reported symptoms.

VII. RECOMMENDATIONS

1. Local exhaust ventilation at the varnish impregnating tanks is inadequate to prevent fire, explosive hazards, or symptoms of solvent intoxication. Ventilation of the impregnating tanks should be improved.

2. The roof fan in the varnish imoregnating department is not under direct control of the department supervisor. Effective use of dilution ventilation by roof fans reçuires easv access to control of that ventilation. Controls for the roof fan should be located in the immediate vicinity of the dip tanks.

3. Institute measures to prevent overcharaing of batteries, and elimination of damaged batteries - conditions which may load to generation of gases and mist by charging batteries.

4. Local exhaust or general dilution ventilation should be installed in the battery charging area to prevent symtoms of sulfuric acid exposure.

5. Install ventilation at the rollover ovens to reduce solvent emissions during the curing of varnish. 
Page 12 - Health Hazard Evaluation Report No. 80-251-252

VIII. AUTHORSHIP/ACKNOWLEDGEMENTS

Report Prepared and Submitted by:

Andrew D. Lucas

Industrial Hygienist

Hazard Evaluations and Technical

Assistance Branch

James Cone, M.D.

Medical Officer

Hazard Evaluations and Technical

Assistance Branch

Environmental Assistance:

G. Edward Burroughs, M.S.

Industrial Hygienist

Hazard Evaluations and Technical

Assistance Branch

Originating office:

Hazard Evaluations and Technical

Assistance Branch

Division of Surveillance, Hazard

Evaluations and Field Studies

Report Typed by

Betty Widener

Clerk/Typist

Industrial Hygiene Section

IX. REFERENCES

1. NIOSH Manual of Analytical Methods, Volume 2, DHEW (NIOSH) Publication No. 77-157B.

2. Ibid

3. NOISH Manual of Analytical Methods, Volume 5, DHEW (NIOSH) Publication No. $79-141$.

4. TLV's Threshold Limit Values for Chemical Substances and Physical Agents in the Workroom Environment with Intended Changes for 1980. American Conference of Governmental Industrial Hygienists 1980, Cincinnati, Ohio.

5. NFPA Handbook of the National Electrical Code Edited by John H. Watt, McGraw Hill Book Company, 1972.

$X$. DISTRIBUTION/AVAILABILITY OF REPORT

Copies of this report are currently available upon request from NIOSH, Division of Technical Services, Information Resources and Dissemination Section, 4676 Columbia Parkway, Cincinnati, Ohio 45226. After 90 days, the report will be available through the National Technical Information Service (NTIS), Springfield, Virginia. Information regarding its 
Page 13 - Health Hazard Evaluation Report No. 80-251-252

availability through NTIS can be obtained from NIOSH at the Cincinnati address.

Copies of this report have been sent to:

1. General Motors, Electro-Motive Division, McCook, Illinois

2. Authorized Representative of Employees, Local 719, United Auto Workers

3. NIOSH, Region $V$

4. OSHA, Region $V$

For the purpose of informing the "affected" employees, the employer shall promptly "post", for a period of 30 calendar-days, this report in a prominent place(s) near where employees work. 
TABLE I

EVALUATION CRITERIA

GENERAL MOTORS, MCCOOK, ILLINOIS

HETA $80-251 / 252$

\begin{tabular}{|c|c|c|c|}
\hline SUBSTANCE & $\begin{array}{c}\text { NIOSH RECOMMENDED } \\
\text { CRITERIA } \\
\end{array}$ & $\begin{array}{l}\text { OSHA PERSONAL } \\
\text { EXPOSURE LIMIT } \\
\end{array}$ & $\begin{array}{l}\text { ACGIH THRESHOL } \\
\text { LIMIT VALUE } \\
\end{array}$ \\
\hline n-butyl acetate & - & $150 \mathrm{ppm}$ & $150 \mathrm{ppm}$ \\
\hline Toluene & $100 \mathrm{ppm}$ & $200 \mathrm{ppm}$ & $100 \mathrm{ppm}$ \\
\hline Ethyl benzene & -- & $100 \mathrm{ppm}$ & $100 \mathrm{ppm}$ \\
\hline Xylene & $100 \mathrm{ppm}$ & $100 \mathrm{ppm}$ & $100 \mathrm{ppm}$ \\
\hline I sobutanol & -- & $100 \mathrm{ppm}$ & $50 \mathrm{ppm}$ \\
\hline Methyl ethyl ketone & 200 & $200 \mathrm{ppm}$ & $200 \mathrm{ppm}$ \\
\hline Sulfuric acid & $1 \mathrm{mg} / \mathrm{M}^{3}$ & $1 \mathrm{mg} / \mathrm{M}^{3}$ & $1 \mathrm{mg} / \mathrm{M}^{3}$ \\
\hline Arsine & $0.05 \mathrm{ppm}$ & $0.05 \mathrm{ppm}$ & $0.05 \mathrm{ppm}$ \\
\hline Stibine & -- & $0.1 \mathrm{ppm}$ & $0.1 \mathrm{ppm}$ \\
\hline Inorganic arsenic & $2.0 \mathrm{ug} / \mathrm{M}^{3}$ ceilin & $10 \mathrm{ug} / \mathrm{M}^{3}$ & $200 \mathrm{ug} / \mathrm{M}^{3}$ \\
\hline
\end{tabular}

\section{HEALTH EFFECTS}

Irritation of eyes, nose and throat. Depresses central nervous system at high concentrations.

Fatigue, weakness, confusion, euphoria, dizziness, headache, nervousness, central nervous system depression.

Irritates skin and mucous membranes, may cause dermatitis.

Irritates skin, eyes, nose throat. High concentrations may cause central nervous system depression: dizziness, excitement, drowsiness, and incoordination.

Irritates eyes, nose \& throat. High concentrations may cause central nervous system depression. Skin irritant.

Irritates eyes, nose \& throat; dermatitis of exposed skin. Repeated exposures of high concentrations may cause numbness of fingers, arms \& legs, dizziness and drowsiness.

Severe irritant of the eyes, respiratory tract \& skin, may cause erosion of teeth. Irritation or tickling sensation of the nose \& throat, sneezing \& coughing.

Attacks blood cells, leading to anemia. Causes abdominal pain, headache, malaise, weakness, dizziness, nausea \& vomiting. May cause liver \& kidney damage.

Attacks blood cells, liver \& kidney damage. Irritates lungs; induces headache, weakness, nausea, abdominal pain, lumbar pain and jaundice.

Irritates skin, mucous membranes cyes. Indures arsenical dermatitis, skin cancer and lung cancer. Mav cause rediening of eyes, visual disturbances, ulceration and perforition of nasal sontum and peripheral neuropathy. 


\section{COMBUSTIBLE GAS METER SURVEY \\ GENERAL MOTORS \\ HETA $80-251 / 252$}

NOVEMBER 11,1980

\section{LOCATION AND CONDITIONS}

Interior of empty impregnating tank

Floor near impregnating tank

Splash guard for xylene dip

Floor near xylol dip

Rim of impregnating tank as the top is opened, prior to removal of armatures

Floor near impregnating tank

Rim of impregnating tank, prior to opening

$6: 22 P M$

TIME

$\%$ LEL*

$4: 15 \mathrm{PM}$

$1-2 \%$

$4: 16 \mathrm{PM}$

$1 \%$

$4: 20$ PM $\quad 10 \%$

$4: 21$ PM $\quad 1 \%$

$6: 20$ PM $20 \%$

Floor near impregnating tank

$7: 30 \mathrm{PM} \quad 1 \%$

Splash guard for xylene dip (fan on)

$7: 30 \mathrm{PM} \quad 1 \%$

6" above xylene (fan on)

$7: 32$ PM $\quad 0.8 \%$

$7: 32$ PM $\quad 1 \%$

Rim of impregnating tank as the lid is lifted

$7: 35 \mathrm{PM} \quad 35-38 \%$

Floor near impregnating tank

$7: 37$ PM $\quad 1.2 \%$

Rim of impregnating tank as the lid is lifted

$11: 30 \mathrm{PM}$

$19 \%$

*LEL $=$ Tower expTosive Timit 
TABLE III

AEROMETRIC SAMPLING IN VARNISH IMPREGNATING DEPARTMENT FOR N-BUTYL ACETATE, TOLUENE M-XYLENE, ETHYL BENZENE, METHYL ETHYL KETONE, AND ISOBUTANOL

GENERAL MOTORS, MCCOOK, ILLINOIS

HE $80-251 / 252$

\begin{tabular}{|c|c|c|c|c|c|c|c|c|c|c|c|}
\hline JOB/LOCATION & $\begin{array}{l}\text { DATE } \\
\text { OF } \\
\text { SAMPLE }\end{array}$ & TIME OF SAMPLE & $\begin{array}{l}\text { SAMPLE } \\
\text { VOLUME } \\
\text { (Liters) } \\
\end{array}$ & $\begin{array}{c}\text { TYPE } \\
\text { OF SAMPLE } \\
\end{array}$ & $\begin{array}{l}\text { N-BUTYL } \\
\text { ACETATE } \\
\text { (PPM) } \\
\end{array}$ & $\begin{array}{l}\text { TOLUENE } \\
\text { (PPM) }\end{array}$ & $\begin{array}{c}\text { M-XYLENE } \\
(P P M) \\
\end{array}$ & $\begin{array}{l}\text { ETHYL } \\
\text { BENZENE } \\
\text { (PPM) } \\
\end{array}$ & $\begin{array}{l}\text { METHYL } \\
\text { ETHYL } \\
\text { KETONE } \\
\text { (PPM) } \\
\end{array}$ & $\begin{array}{l}\text { ISOBUTANOL } \\
\text { (PPM) } \\
\end{array}$ & $\begin{array}{l}\text { ACGIH } \\
\text { TLV of } \\
\text { MIXTURE } \\
\text { \& of TLY } \\
\end{array}$ \\
\hline $\begin{array}{l}\text { Impregnator, during } \\
\text { armature removal from } \\
\text { impregnating tank }\end{array}$ & $11-11-80$ & $6: 17 p-6: 27 p$ & 11 & Personal & 3.8 & ND & ND & ND & 3.1 & 6.6 & 17 \\
\hline Squeeze Box Operator & $11-11-80$ & $5: 16 P-12: 19 A$ & 43 & Personal & 0.3 & 0.1 & 0.4 & 0.2 & 0.4 & 0.3 & 1 \\
\hline Coil Winder & " & $5: 01 p-7: 07 p$ & 10 & & 0.6 & ND & 0.5 & 0.2 & 0.7 & 0.5 & 2 \\
\hline Armature Winder & $"$ & $4: 53 P-12: 20 A$ & 44 & " & 0.4 & 0.1 & 0.3 & 0.2 & 0.8 & 0.4 & 2 \\
\hline Main Winder & $"$ & $4: 47 P-12: 16 A$ & 46 & $"$ & 0.5 & 0.2 & 0.4 & 0.2 & 1.8 & 0.4 & 3 \\
\hline Cutoff Machine Operator & or " & $4: 43 P-12: 23 A$ & 46 & $"$ & 0.4 & 0.1 & 0.4 & 0.2 & 0.3 & 0.4 & 2 \\
\hline Wedger & $"$ & $4: 35 P-12: 20 A$ & 46 & " & 1.1 & 0.2 & 0.7 & 0.4 & 0.9 & 1.2 & 5 \\
\hline Torque Rack Operator & " & $4: 34 \mathrm{P}-12: 20 A$ & 44 & $"$ & 0.6 & 0.2 & 0.8 & 0.3 & 0.5 & 0.5 & 3 \\
\hline Wedger & " & $4: 32 P-12: 20 A$ & 46 & $"$ & 1.0 & 0.2 & 0.7 & 0.4 & 0.8 & 0.4 & 3 \\
\hline Arma ture Winder & " & $4: 29 P-12: 17 A$ & 46 & " & 0.4 & 0.1 & 0.3 & 0.2 & 0.8 & 0.5 & 2 \\
\hline Impregnator & $"$ & $4: 27 \mathrm{P}-12: 18 \mathrm{~A}$ & 49 & $"$ & 1.3 & 0.3 & 1.0 & 0.6 & 0.8 & - & 3 \\
\hline Impregnator & $11-12-80$ & $4: 40 P-11: 59 P$ & 44 & $"$ & 0.7 & 0.2 & 0.4 & 0.4 & 0.6 & 0.8 & 3 \\
\hline Armature Winder & " & $4: 43 P-11: 59 P$ & 47 & $"$ & 0.4 & 0.2 & 0.4 & 0.2 & 1.9 & 0.4 & 3 \\
\hline Anma ture Winder & " & $4: 44 P-11: 55 P$ & 44 & " & 0.8 & 0.2 & 0.4 & 0.2 & 1.3 & 0.7 & 3 \\
\hline Wedger & $"$ & $4: 46 P-12: 08 A$ & 44 & $"$ & 0.7 & 0.2 & 0.7 & 0.4 & 0.7 & 0.8 & 4 \\
\hline Wedger & " & $4: 48 P-11: 59 P$ & 42 & $"$ & 0.5 & 0.2 & 0.5 & 0.3 & 0.5 & 0.4 & 2 \\
\hline Torque Rack Operator & $"$ & $4: 52 P-12: 03 A$ & 43 & $"$ & 0.5 & 0.2 & 0.8 & 0.3 & 0.5 & 0.5 & 3 \\
\hline Armature Winder & " & $4: 56 P-11: 59 p$ & 43 & " & 0.4 & 0.2 & 0.4 & 0.2 & 2.0 & 0.5 & 3 \\
\hline Cuttoff Machine & $"$ & $4: 59 P-12: 06 A$ & 41 & $"$ & 0.3 & 0.2 & 0.4 & 0.2 & 0.3 & 0.2 & 2 \\
\hline call Winder & $"$ & $5: 03 P-7: 31 P$ & 15 & $"$ & 0.4 & ND & 0.5 & 0.2 & 0.5 & 0.4 & 2 \\
\hline Cutoff Operator & $"$ & $5: 08 \mathrm{P}-12: 06 \mathrm{~A}$ & 45 & $"$ & 0.2 & 0.1 & 0.3 & 0.1 & 0 . & 0.2 & 1 \\
\hline Stoker \& Insulator & $"$ & $5: 42 p-11: 54 P$ & 36 & $"$ & 0.7 & 0.2 & 0.9 & 0.1 & 1.2 & 0.6 & 3 \\
\hline Impregnator's Work & $"$ & $5: 11 P-11: 24 P$ & 39 & Area & 0.3 & & & & 0.3 & - & \\
\hline $\begin{array}{l}\text { Bench, 3' Above Floor } \\
\text { Impregnators work }\end{array}$ & " & $5: 11 P-11: 25 P$ & 370 & Area & 0.4 & 0.2 & 0.6 & 0.2 & 0.4 & - & 1 \\
\hline $\begin{array}{l}\text { Bench, 3' Above Floor } \\
\text { Torque Rack Work Bench }\end{array}$ & $h "$ & $5: 13 P-11: 26 P$ & 370 & Ared & - & - & - & - & - & 1.5 & 3 \\
\hline General Area, Rollover & 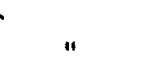 & $5: 18 P-11: 25 P$ & 37 & Area & - & - & - & - & - & 1.0 & 2 \\
\hline $\begin{array}{l}\text { Ovens } \\
\text { Toroue Rack Work Bench }\end{array}$ & $"$ & $5: 13 P-11: 26 P$ & 38 & Area & - & 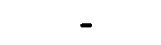 & - & - & - & 0.5 & 1 \\
\hline $\begin{array}{l}\text { Iorque Rack work bencn } \\
\text { OSHA Personal Exposure } \\
\text { ACGIH TLV }\end{array}$ & Limit & & & & $\begin{array}{l}150 \\
150\end{array}$ & $\begin{array}{l}200 \\
100\end{array}$ & $\begin{array}{l}100 \\
100\end{array}$ & $\begin{array}{l}100 \\
100\end{array}$ & $\begin{array}{l}200 \\
200\end{array}$ & $\begin{array}{r}100 \\
50\end{array}$ & \\
\hline
\end{tabular}

₹To minute sample 
TABLE IV

ENVIRONMENTAL RESULTS - AEROMETRIC SAMPLING FOR SULFURIC ACID BATTERY CHARGING AREA GENERAL MOTORS INC., MCCOOK, ILLINOIS

HE $80-251 / 252$

\title{
JOB TITLE/LOCATION
}

Battery Charging Station $\# 75$

Battery Charging Station \#31

On Wall Between Battery Charging Area and Surface Grinder

On Shelf of Surface Gringer

On Wall Between Battery Charging Area and Drill Press

On Wall Between Battery Charging Area and Surface Grinder

On Wall Between Battery Charging Area and Drill Press On Shelf of Surface Grinder

Electrician

On Wall Between Battery Charging and Drfll Press

Large Mil1 Operator EM87416

Radial Drilll Operator

Radial Drill Operator

Large Mill Operator

Assembler

Tape Control G\&L Operator

On Wall Between Battery Charging Area and Surface Grinder

Electrician

Electrician

Tape Puller

Radial Press Operator

Large M111 Operator EM93401

On Wall Between Battery Charging Station and Surface Grinder

On Shelf of Surface Grinder

DATE OF

SAMPL ING

$9-29-80$

$11-12-80$

$11-12-80$

$11-12-80$

$11-13-80$

$11-13-80$

$11-13-80$

$11-13-80$

$11-13-80$

$11-13-80$

$11-13-80$

$11-13-80$

$11-13-80$

$11-1380$

$11-13-80$

$11-13-80$

$11-13-80$

$11-14-80$

$11-14-80$

$11-14-80$

$11-14-80$

$11-14-80$

$11-14-80$
TYPE OF

SAMPLE

A

A

A

A

A

A $\quad 0020-0740$

A $\quad 0021-0805$

P $\quad 0730-1431$

0850-1410

0743-1417

$0747-1424$

$0752-1446$

$0755-1428$

$0759-1429$

0807-1420

$0831-1410$

0939-1155

0715-1440

$0732-1433$

0735-1437

0740-1438

0810-1430

$0810-1430$
SAMPLE VOLUME (LITERS)

\begin{tabular}{|c|c|}
\hline $\begin{array}{l}550 \\
560 \\
510\end{array}$ & $\begin{array}{l}0.036 \\
0.031 \\
0.026\end{array}$ \\
\hline $\begin{array}{l}500 \\
510 \\
740\end{array}$ & $\begin{array}{l}0.040 \\
0.012 \\
0.016\end{array}$ \\
\hline $\begin{array}{l}660 \\
700 \\
630 \\
480 \\
590 \\
600 \\
620 \\
590 \\
590 \\
560 \\
510\end{array}$ & $\begin{array}{l}0.008 \\
0.033 \\
0.016 \\
0.013 \\
0.027 \\
0.015 \\
0.015 \\
0.014 \\
0.014 \\
0.027 \\
0.028\end{array}$ \\
\hline $\begin{array}{l}200 \\
670 \\
630 \\
630 \\
630 \\
570\end{array}$ & $\begin{array}{l}\text { BLD } \\
0.015 \\
0.014 \\
0.010 \\
0.011 \\
0.019\end{array}$ \\
\hline 570 & $\begin{array}{l}0.021 \\
1.0\end{array}$ \\
\hline
\end{tabular}

OSHA Personal Exposure L1mit

\begin{abstract}
[imit of Detection $=5 \mathrm{ug}$.
\end{abstract}
$B L D=$ Below Limt of Detection

$P=$ Personal

$A=$ Area 
TABLE $V$

ENVIRONMENTAL RESULTS - AEROMETRIC SAMPLING FOR ARSINE AND STIBINE $9-29,11-12,11-13$, and 11-14-80 - BATTERY CHARGING AREA GENERAL MOTORS INC., MCCOOK, ILLINOIS

HE $80-251 / 252$

\section{JOB TITLE/LOCATION}

\section{Battery Station \#41}

Battery Station \$32

Battery Station $\$ 75$

Between Battery Stations "\#38\& \#39

On Wall Between Battery Charging Area

and Surface Grinder

Shelf of Surface Grinder

On Wall Between Battery Charging \& Drill Press

On Wall Between Battery Charging Area

and Surface Grinder

On Wall Between Battery Charging \& Drill Press

On Shelf of Surface Grinder

On Wall Between Battery Charging Area and and Surface Grinder

On Wall Between Battery Charging \& Drill Press

Electrician

Radial Drill Operator

Large Mill Operator EM87416

Large Mill Operator

Radial Drill Operator

Assembly Operator

Tape Control G\&L Operator

Electrician

On Wall Between Battery Charging \& Radial Drill

Radial Drill Operator

Tape Puller

Radial Press Operator

Assembler*

Large Mill Operator EM93401

On Wali Between Battery Charging Large Mili

Electrician

On Shelf of Large Mill

Radial Drill Operator

PEL (OSHA)

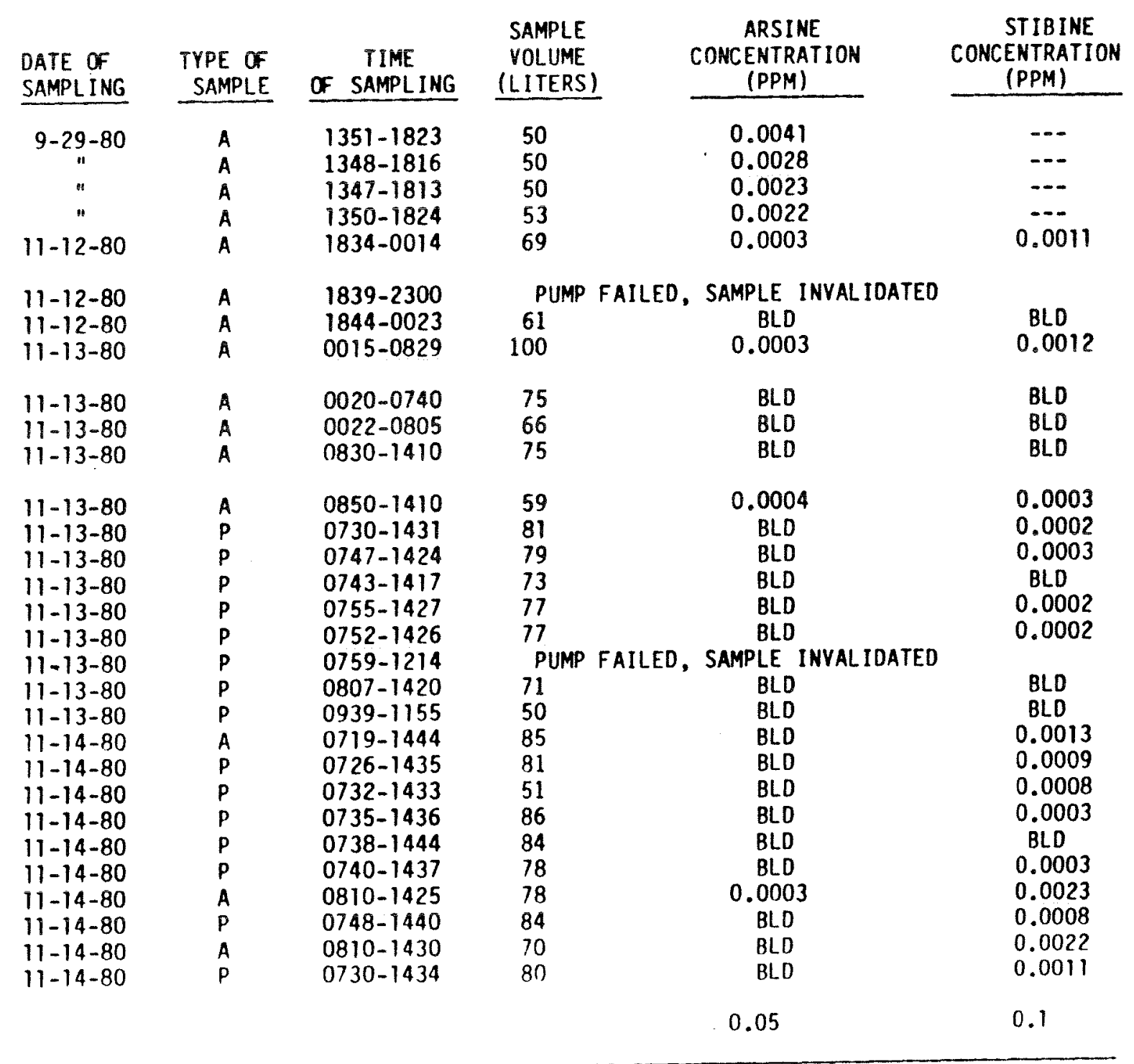

* Left the area at 12:00 and placed pump on foreman's desk.

$P=$ Personal $\quad A=$ Area $B L D=$ below limit of detection 
TABLE VI

ENVIRONMENTAL RESULTS - AEROMETRIC SAMPLING FOR ARSENIC; BATTERY CHARGING AREA GENERAL MOTORS INC., MCCOOK, ILLINOIS

HE $80-251 / 252$

\section{JOB TITLE/LOCATION}

On Wall Between Battery Charging Area \& Radial Drill Large Mill Operator EM87416

Radial Drill Operator

Radial Drill Operator

*Assembler

NIOSH Recommended Criteria

\begin{tabular}{|c|c|c|}
\hline $\begin{array}{c}\text { DATE } \\
\text { SAMPLING }\end{array}$ & $\begin{array}{l}\text { TYPE OF } \\
\text { SAMPLE }\end{array}$ & $\begin{array}{c}\text { TIME } \\
\text { OF SAMPLING }\end{array}$ \\
\hline $11-14-80$ & A & $0719-1440$ \\
\hline $11-14-80$ & $p$ & $0724-1445$ \\
\hline $11-14-80$ & $p$ & $0726-1426$ \\
\hline $11-14-80$ & $p$ & $0730-1434$ \\
\hline $11-14-80$ & $P$ & $0738-1444$ \\
\hline
\end{tabular}

$11-14-80$

\begin{tabular}{c}
$\begin{array}{c}\text { SAMPLE VOLUME. } \\
\text { (LITERS) }\end{array}$ \\
\hline 660 \\
660 \\
630 \\
640 \\
640
\end{tabular}




\section{TABLE VII}

FREQUENCY OF SYMPTOMS AMONG BATTERY CHARGING

AND NON-BATTERY CHARGING AREA WORKERS

GENERAL MOTORS INC., MCCOOK, ILLINOIS

HE $80-251 / 252$

SYMPTOMS

(IN PAST MONTH)

*Sore Throat

*Eye Pain

$\star \star$ Respiratory Irritation

Runny Nose

Itching Skin

Skin Rash

Nosebleeds

Burning Skin

Painful Teeth

Conjunctivitis

Frequent URI's

Tickling of Throat

Headache

\section{FREQUENCY}

BATTERY CHARGING

AREA $(N=18)$

\#

13

$44 \stackrel{i}{c}$

$72 \%$

$72 \%$

$33^{\circ}$

$50 \%$

$22 \%$

$11 \%$

$22 \%$

$11 \%$

$22 \%$

$27 \%$

$38 \%$

$5 \quad 27 \%$
NON-BATTERY

CHARGING AREA $(N=39$

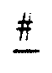

$\underline{q}$

$15 \%$

$15 \%$

13

$34 \%$

8

$21 \%$

13

$39 \%$

8

$21 \%$

$2 x$

$0 \%$

$0 \%$

$0^{\circ}$

$0 \%$

4

$11 \%$

13

30

$\star p<.05$

$\star \star p<.01$ 
TABLE VIII

PREVALENCE OF SYMPTOMS

GENERAL MOTORS INC., MCCOOK, ILLINOIS

HE $80-251 / 252$

TRACTION MOTOR ARMATURE IMPREGNATING DEPARTMENT

\begin{tabular}{|c|c|c|c|c|c|c|}
\hline JOB CLASSIFICATION & HEADACHE & NUMBNESS & $\begin{array}{l}\text { SYMPTOMS } \\
\text { DIZZINESS }\end{array}$ & NAUSEA & FEELING OF & BEING "HIGH" \\
\hline $\begin{array}{l}\text { Armature Winder } \\
\%(n=15)\end{array}$ & $\begin{array}{l}1 \\
6 \%\end{array}$ & $\begin{array}{l}1 \\
6 \%\end{array}$ & $\begin{array}{l}0 \\
0 \%\end{array}$ & $\begin{array}{c}2 \\
13 \%\end{array}$ & & $\begin{array}{l}1 \\
6 \%\end{array}$ \\
\hline $\begin{array}{l}\text { Wedger, Staker, Coil } \\
\text { Operator, Impregnator } \\
\%(n=8)\end{array}$ & $\begin{array}{c}2 \\
25 \%\end{array}$ & $\begin{array}{c}3 \\
38 \%\end{array}$ & $\begin{array}{c}4 \\
50 \%\end{array}$ & $\begin{array}{c}1 \\
12.5 \%\end{array}$ & & ${ }_{0 \%}$ \\
\hline $\begin{array}{l}\text { Machine Operator } \\
\%(n=6)\end{array}$ & $\begin{array}{c}4 \\
67 \%\end{array}$ & $\begin{array}{l}0 \\
0 \%\end{array}$ & $\begin{array}{c}2 \\
33 \%\end{array}$ & $\begin{array}{c}4 \\
67 \%\end{array}$ & & $\begin{array}{c}3 \\
33 \%\end{array}$ \\
\hline
\end{tabular}




\section{EPARTMENT OF HEALTH AND HUMAN SERVICES}

PUBLIC HEALTH SERVICE

CENTERS FOR DISEASE CONTROL

ATIONAL INSTITUTE FOR OCCUPATIONAL SAFETY AND HEALTH

ROBERT A. TAFT LABORATORIES

4676 COLUMBIA PARKWAY, CINCINNATI, OHIO 45226

Third Class Mail

OFFICIAL BUSINESS

PENALTY FOR PRIVATE USE. $\$ \infty$

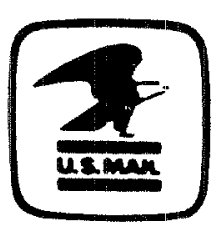

post AGe and FEes PAID U.S. DEPARTMENT OF HHS 